Research article

\title{
SURVEY OF INFECTIOUS AGENTS ASSOCIATED WITH PORCINE RESPIRATORY DISEASE COMPLEX (PRDC) IN SERBIAN SWINE HERDS USING POLYMERASE CHAIN REACTION (PCR) DETECTION
}

\author{
SAVIĆ Božidar ${ }^{1,3 *}$, RADANOVIĆ Oliver ${ }^{1}$, JOVIČIĆ Dubravka ${ }^{2}$, NEŠIĆ Ksenija ${ }^{1}$, \\ IVANOVIĆ Snežana ${ }^{1}$, STEVANČEVIĆ Ognjen ${ }^{3}$, CVETOJEVIĆ Đorđe ${ }^{1}$, KASAGIĆ \\ Dragan $^{4}$

\begin{abstract}
${ }^{1}$ Institute of Veterinary Medicine Belgrade, Serbia; ${ }^{2}$ "Singidunum" University, Faculty of Applied Ecology, Belgrade, Serbia; ${ }^{3}$ Faculty of Agriculture, Department for Veterinary Medicine, University of Novi Sad, Serbia; ${ }^{4}$ Veterinary Institute of the Republic of Srpska "Dr Vaso Butozan", Banja Luka, Republic of Srpska
\end{abstract}

(Received 27 $7^{\text {th }}$ May; Accepted 22 ${ }^{\text {nd }}$ December 2014)

\begin{abstract}
A retrospective study on 235 natural cases of Porcine Respiratory Disease Complex in order to determine the etiological agents, their prevalence and interrelationships was performed in Serbia. Lung tissue samples were analyzed by Polymerase Chain Reaction for the presence of Porcine circovirus type 2, Porcine reproductive and respiratory virus, Swine inflienza virus, M yooplasma hyopneumoniae, Pasteurella multocida, A ctinobacillus pleuropneumoniae, H aemophilus parasuis, Streptococcus suis and A rcanobacterium pyogenes. A total of 49 different combinations of viral and bacterial pathogens were found. Five different viral and viral/Mhp co-infections were detected. Monobacterial infections were found in 150 cases and polybacterial infection was detected in 85 samples. PCV2 was the main virus detected, and Pm was the most aggressive secondary pathogen detected in PRDC. The reason for PRDC being so prevalent among Serbian pigs is most likely due to the large number of risk factors in the conventional farrow-to-finish system, compared to multisite production systems. Therefore, measures aimed at a better control of respiratory viruses, particularly Porcine circovirus type 2 and Porcine reproductive and respiratory virus, as well as Myoplasma hyopneumoniae infections, and adoption of rational decisions on respiratory bacterial pathogens specific therapeutic and preventive strategies at herd level, simultaneously with significant improvements on farm management should reduce the occurrence of PRDC.
\end{abstract}

Key words: farm pigs, respiratory diseases, etiological agents, PRDC, PCR

\section{INIRODUCTION}

Porcine respiratory disease complex (PRDC) is a common term for pneumonia in finishing or fattening pigs caused by a multifactorial etiology [1,2]. A large number of

Corresponding author: e-mail: savic.bozidar@hotmail.com 
etiological factors are involved in the pathogenesis of PRDC, of which infective agents have the leading role, and they can be divided into four groups namely: viral respiratory pathogens (Porcine Reproductive and Respiratory syndrome virus (PRRSV), Porcine circvirus type 2 (PCV2), Porcine Cytomegalo V irus (PCMV) and Porcine Respiratory Corona V irus (PRCV)); primary bacterial respiratory pathogens (Myooplasma hyopneumoniae (M hp), A ctinobacillus pleuropneumoniae (A pp) and Bordetella bronchiseptica (Bord)); opportunistic bacterial respiratory pathogens (Pasteurella multocida (Pm), Streptococaus suis (Ssuis) and $\mathrm{H}$ aemophilus parasuis (Hps)); septicemic causes of pneumonia (Salmonella enterica (Salm), A ctinobacillus suis (Asuis) and A ranobacterium pyogenes (Apyo)) [1,2]. The etiology of PRDC varies between and within production herds and/or systems, however, the combination of primary and opportunistic infectious agents is generally involved [3]. Combinations of viruses and/or Mhp and opportunistic bacteria have been reported to work in a synergistic fashion producing more severe and/or fatal pneumonias then those induced by each individual agent [4]. The most common respiratory pathogens reported are Mhp, PRRSV, PCV2, Pm, App, Hps and Sspp [5-8]. PRDC is frequent and usually present in farrow-to-finish systems in Serbia, however, a comprehensive survey of the pathogens involved in PRDC in Serbian pigs has never performed. In recent years the considerable genetic diversity of some respiratory pathogens has been described $[9,10]$ and a survey of respiratory pathogens in pigs has become relevant. Therefore, the objectives of this investigation were to detect the viral and bacterial pathogens, to determine the prevalence, and interrelationships of the detected microorganisms in the lung lesions of pigs which died from PRDC, originating from ten conventional farrow-to-finish pig farms chosen as representative of the Serbian swine industry.

\section{MATERIALAND METHODS}

The survey was carried out from September 2011 to August 2012 on ten pig farms. The studied farms were located in the north (Vojvodina province, 8 farms) and central part of Serbia (central Serbia, 2 farms) where approximately $85 \%$ of Serbian market pigs are produced. The farms in the study were all single site farrow-to-finish, with a 1200 to 1500 sows per farm, producing about 8\% of market pigs in Serbia. All farms practiced continuous flow operations, and had poor management of health issues including: biosecurity, strategy to minimize disease challenge, inadequate sanitation, room management and vaccination scheme, as well as housing-environmentalmanagement shortcomings. All farms included in the study had never implemented vaccination against PRRSV, PCV2, and only two farms had vaccinated against App, Pm and Hps previously. On four farms, vaccination against Mhp was irregularly applied. Respiratory diseases, were the most important cause of death in weaned and growing-finishing pigs. Overall mortality from wean-to-finish, during the period from the end of October 2011 to late-April 2012, reached 22-40\%, whilst the mortality rates due to respiratory disease ranged from $20-37 \%$. Thereafter, the total mortality (from 
wean-to-finish) was gradually decreased, and at the end of the survey (August 2012), the mortality rate due to respiratory diseases, ranged from 9-15\%. Each farm was visited once, at the mortality peak (20-37\%), in weaned and grow-finishing pigs (from November 2011 to March 2012), for observation and collection of suspected material for further investigation. On necropsy, pneumonic lungs from at least 20 of the dead, weaned (8-12 weeks of age) and growing-finishing (12-25 weeks of age) pigs, were collected for laboratory testing. Macroscopic lung lesions which were most frequently observed included: (a) bronchointerstitial pneumonia, (b) pleuropneumonia, (c) suppurative pneumonia and (d) pneumonia with abscesses, respectively. Resection of the trachea up to the bifurcation was performed and sterile PBS was administered into both bronchi. Samples were taken with cotton swabs by immersion into the contents from the caudal lung lobe and by swabbing the mucosa of the bronchus, trachea and lesions. Swab tubes were additionally filled with $2 \mathrm{ml}$ of sterile phosphate buffered saline (PBS).

In the laboratory, $1 \mathrm{ml}$ of suspension from each tube was centrifuged at 14,000 $\mathrm{g}$ (Hettich Micro 20) for $10 \mathrm{~min}$, washed in sterile PBS and resuspended in $180 \mu \mathrm{l}$ of ATL buffer. The samples were incubated in $400 \mu$ l proteinase $\mathrm{K}$ lysis buffer for $1 \mathrm{~h}$ at $60{ }^{\circ} \mathrm{C}$. The lysed samples were processed with a DNA extraction kit (QIA extraction DNA kit, Qiagen) according to the manufacturer's instructions. All samples were tested by PCR using HotStarTaq Master Mix Kit (Qiagen), and primers described for DNA detection of PCV2 [11], Mhp [12], Pm [13], App [14], Hps [15], Ssuis [16] and Apyo [17]. After suspension, the samples were processed with a RNA extraction kit (Qiagen - Rneasy MiniKit) according to the manufacturer's instructions. For detection of PRRSV, RT-nested PCR (OneStep RT-PCR Kit; HotStarTaq Master Mix Kit Qiagen) specific for ORF 7 [18], and for SwineInflienza V irus (SIV) detection, RT-PCR (OneStep RT-PCR Kit - Qiagen) specific for type A influenza virus were used [19].

To determine, whether the viral, and/or the viral/Mhp co-infections which were detected varied in prevalence, whether there were significant differences between the prevalence of mixed infections, and to assess the significance of the association among viral and/or viral/Mhp co-infections, with Pm, App, Hps, Ssuis and Apyo, contingency tables and Chi-squared tests were used for statistical analyses.

\section{RESULTS}

In total, DNA target sequences from PCV2, Mhp, PRRSV, SIV, Pm, App, Hps, Ssuis and Apyo were detected in 207, 185, 141, 4, 137, 87, 76, 33 and 10 of the samples, respectively. Of the 235 samples examined, PCV2/Mhp, PCV2/PRRSV/ Mhp, PCV2/PRRSV, PCV2/PRRSV/SIV/Mhp and PRRSV/Mhp co-infections, in combination with other bacterial respiratory pathogens were detected in $94(40 \%)$, $59(25 \%), 50(21.2 \%), 28(11.9 \%)$, and $4(1.7 \%)$ of the samples, respectively, (Table 1). Along with these five viral, and viral/Mhp co-infections detected, DNA, from Pm (57\%), App (37\%), Hps (32.3\%), Ssuis (14\%) and Apyo (4.2\%) was also detected 
in the samples examined. Mono bacterial infections were detected in $150(63.8 \%)$ samples whereas $85(36.1 \%$ ) samples yielded poly-bacterial infections (Table 2). A total of 49 different combinations of viral and bacterial pathogens were found in PRDC cases examined. However, mixed infection where three agents were involved was the most frequently detected pattern (116/235), followed by situations where $4(79 / 235)$, $5(27 / 235), 6(11 / 235)$ and $7(2 / 235)$ agents were detected respectively (Table 1$)$. Statistically, these differences were significant $(\mathrm{p}<0.01)$, and indicating that in pigs which are suffering from PRDC, there is almost a 50\% possibility that at least three agents, are most frequently involved in the pathogenesis of the disease. The most frequently detected 3-agent combination was PCV2/Mhp/Pm (26/116 cases). The most common 4-agent combination cases were PCV2/PRRSV/Mhp/Pm (12/79). Five agent combination cases comprising PCV2/PRRSV/Mhp/Pm/APP (8/27) were seen most often, while when six agents combination cases were found, PCV2/ PRRSV/Mhp/Pm/APP/Hps (4/11) were the pathogens found most often. Seven agents mixed infections $(2 / 235)$ were rare but the two cases found had the following pathogens present PCV2/PRRSV/Mhp/Pm/APP/Hps/Ssuis and PCV2/PRRSV/ $\mathrm{Mhp} / \mathrm{Pm} / \mathrm{APP} / \mathrm{Hps} /$ Apyo. However, the PCV2/Mhp co-infection (94/235), was detected significantly more $(\mathrm{p}<0.01)$, than other viral, and/or viral/Mhp co-infections, thus implicating PCV2 and Mhp, as the two most common agents, in PRDC cases (Table 2). Nevertheless, together, the others viral, and/or viral/Mhp co-infections $(141 / 235)$, were significantly more often detected $(\mathrm{p}<0.05)$ compared to the PCV2/ Mhp co-infection (94/235).

In addition to Mhp, the highest detected bacterial pathogen in examined PRDC cases

Table 1.

\begin{tabular}{lccccc}
\hline Agents & $\mathbf{n}=$ samples & $\mathbf{\%}$ & mixed infection & Total & $\%$ \\
\hline PCV2+Mh & 94 & 40 & 3-agent mixed inf. & 116 & 49.3 \\
PCV2+PRRS+Mh & 59 & 25 & 4-agent mixed inf. & 79 & 33.6 \\
PCV2+PRRS & 50 & 21.2 & 5-agent mixed inf. & 27 & 11.4 \\
PRRS+Mh & 28 & 11.9 & 6-agent mixed inf. & 11 & 4.6 \\
PCV2+PRRS+SIV+Mh & 4 & 1.7 & 7-agent mixed inf. & 2 & 0.8 \\
\hline TOTAL & 235 & 100 & 5 & 235 & 100 \\
\hline
\end{tabular}

Viral and viral/Mhp co-infecions (the first three columns), as well as mixed (viral/bacterial) infections (the last three columns) in which three, four, five, six or seven agents were detected by PCR, in lung tissue samples of 235 PRDC cases studied, originating from ten conventional farrow-to-finish pig farms in Serbia.

was $\operatorname{Pm}(137 / 235)$, which is significantly associated $(\mathrm{p}<0.01)$ with all viral, and/or viral/ Mhp co-infections detected, as well as with other opportunistic bacterial respiratory pathogens, App and Apyo. The App was significantly more $(\mathrm{p}<0.01)$ detected with the PCV2/PRRSV (15/50) and PRRS/Mhp co-infections (13/28) in examined PRDC 


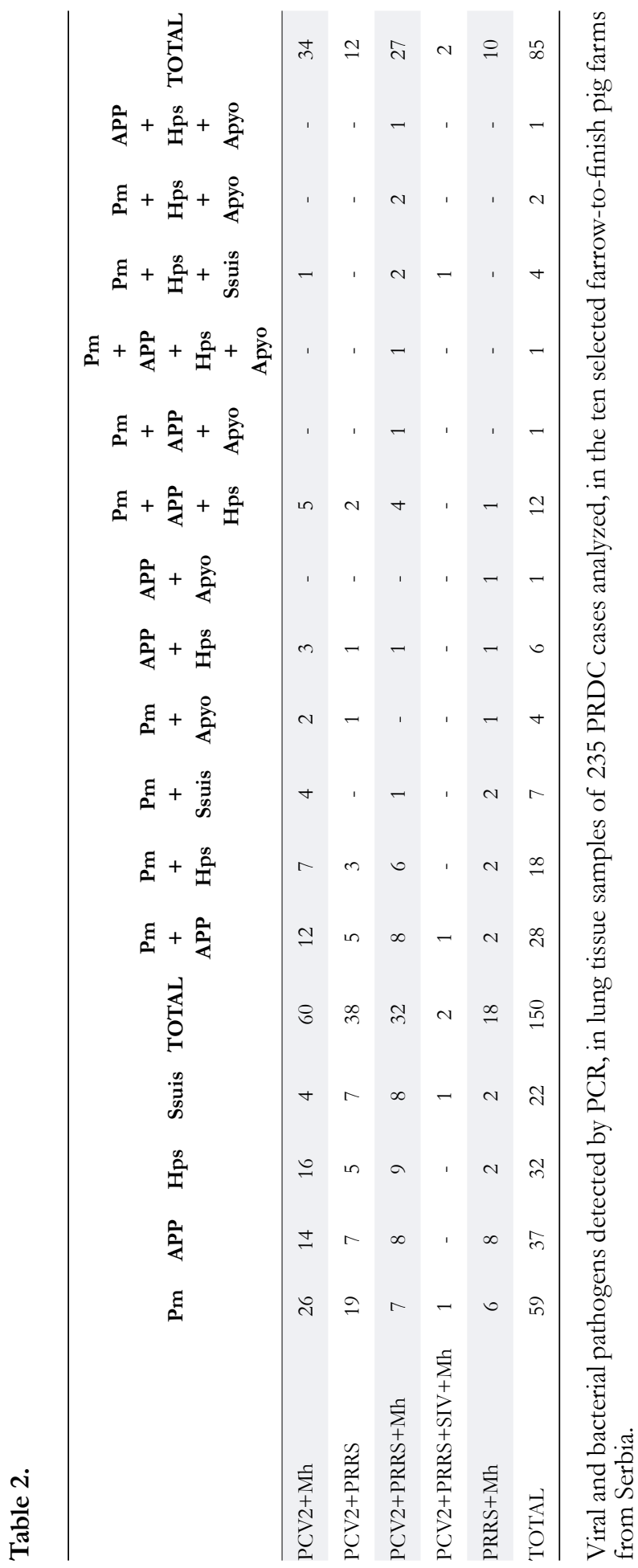


cases. The Hps is significantly more associated $(\mathrm{p}<0.01)$ with the PRRSV/Mhp and PCV2/Mhp co-infections, while the Ssuis is significantly associated $(\mathrm{p}<0.01)$ with PCV2/PRRSV/Mhp co-infection.

Finally, the Apyo can be found in samples with all viral, and/or viral/Mhp coinfections, in studied PRDC cases.

It was not possible to compare the association of SIV with other pathogens since it was detected only in a few samples.

\section{DISCUSSION}

The results of this survey provide a further insight into the prevalence and diversity of major infectious agents, and their interrelationships in PRDC. However, the most significant conclusion indicates that PCV2, Mhp, PRRSV and Pm were the most frequently present pathogens in PRDC in studied the pigs. Moreover, the frequency of occurrence of certain pathogen profiles in the cases examined allows the prediction of the most common infectious patterns which lead to the emergence of PRDC.

The here obtained results show that PCV2 is the most prevalent pathogen detected in the majority of lung samples examined although using PCR as a method for PCV2 identification may be inconclusive on the importance of this virus for the induction of pathological lesions in the lungs. Accordingly, the PRDC cases we examined can be seen as field models, demonstrating that PCV2 replication and associated lesions can be enhanced by concurrent infection with other viruses or bacteria though the exact mechanisms by which concurrent pathogens upregulate PCV2 are unknown [20]. Interestingly if PCV2 is excluded from any pathogen combination, detected in this study, PRDC remains the most common mixed respiratory infection (141/235), compared with "classical" enzootic pneumonia which is significantly less present (94/235), suggesting that PRDC is the most prevalent respiratory disease in the swine population. Therefore, these findings are in accordance with other reports on the high prevalence of PRDC, and the significant association of PCV2 in PRDC in naturally infected pigs using both, PCR [6] and in situ hybridization (ISH) detection of PCV2 [21].

The high prevalence of PRRSV detected in the PRDC cases in this study strongly supports an important role of PRRSV in PRDC and implicates PRRSV as an important viral respiratory agent in the Serbian swine herds. In addition, the high detection rate of Mhp in the studied PRDC cases is in line with the results of other reports on the role of Mhp as a primary bacterial respiratory pathogen in this complex, preparing the way for others to produce more severe lesions [3,7].

Pasteurella multocida was significantly associated with all viral, and/or viral/Mhp combinations detected in this study, as well as with other opportunistic bacteria. This confirms that Pm most likely does not act as a primary pathogen but rather follows infections with other agents. It does significantly aggravates the lung lesions in PRDC 
which have experienced earlier infections by immunosuppressive viruses and Mhp [22].

As App is a primary bacterial respiratory pathogen, able to cause the disease on its own, the high co-occurrence of App and viral or viral/Mhp co-infections in PRDC cases from this study is probably coincidental, however, its participation in the PRDC is significant compared with some other field studies $[5,6]$ indicating a high prevalence of App in the Serbian swine population. This suggests high infection pressure, probably generated from the continuous operation flow and mixing of the different age groups of pigs that share the same air space.

$\mathrm{H}$ aemophilus parasuis is considered as a common inhabitant of the upper respiratory tract of asymptomatic pigs raised under commercial conditions and as one of the opportunistic bacterial respiratory pathogens in PRDC [23]. Thus, relatively high prevalence of Hps in the polybacterial lesions in this PRDC study (onethird of the samples were positive for Hps) may be attributed to the simultaneous immunosuppressive effects of the viruses and Mhp, which caused an increased number of the bacteria including the Hps in the lungs. Furthermore, in Hps-monobacterial infections (32/235), the most probable cause of pig death was septic shock emerging as a result of rapid proliferation of Hps in the immunocompromised lungs [24].

Since the role of Ssuis as a primary agent in pulmonary lesions in the absence of other pathogens is still controversial [1], in the PRDC, it was recognized as an opportunistic bacterial pathogen. Therefore, septicemia is the most likely reason, for a significantly higher detection of this pathogen in mono, than in mixed bacterial infections of PRDC samples from our study (22/32).

A rcanobacterium pyogenes is another common pathogen on the mucous membranes of the upper respiratory tract [25]. However, devitalized or inflamed tissue is a prerequisite for Apyo to cause suppurative inflammation and abscessation, therefore in the lungs, it acts as a secondary invader in a pre-existing pneumonia. Many pathogens including PRRSV and Pm may damage the upper respiratory tract epithelium [26] creating a portal for Apyo. Nevertheless, Apyo is not a typical respiratory pathogen and its detection with accompanying lesions in the lungs from the PRDC cases in this study may be illustrative of the extraordinary versatility of Apyo as a pathogen.

Ourstudy confirms that PRDC involves multiple pathogens and that the microorganisms most commonly associated with the PRDC are present and widespread in conventional farrow-to-finish systems. The previously reported occurrence of corresponding pathogen profiles in PRDC is confirmed by the results of the present study. PCV2 appears to be the major viral pathogen involved in PRDC, however its role is likely to be centered on the interaction with other pathogens. PRRSV was the next most common virus participating in PRDC, and although there were too few positive SIV samples, it does indicate that SIV is circulating in the Serbian swine population. Beside 
Mhp, the Pm was the individually the highest detected bacteria, indicating Pm primarily, as the most aggressive secondary pathogen in the PRDC cases studied.

Respiratory diseases among Serbian pigs seem to currently tend toward PRDC definition, compared to enzootic pneumonia. Explanation for this can be both, the introduction of sophisticated methods for detection of respiratory pathogens, particularly for PCV2, and Mhp detection, and the presence of a larger number of risk factors for respiratory diseases occurrence in conventional farrow-to-finish systems. The latter can provide more opportunities for multiple interactions between pathogens, compared to multi-site production systems.

\section{Acknowledgments}

We thank Professor Willie Donachie (Moredun Research Institute, Edinburgh, Scotland, UK) for critical reading of the manuscript and improving the English. This work was partly funded by Serbian Ministry of Education, Science and Technological Development (project number: TR 31062).

\section{REFERENCES}

1. Brogden KA, Guthmiller JM: Polymicrobial Diseases. Washington (DC): ASM Press. [http://www.ncbi.nlm.nih.gov/books/NBK2475/.].

2. Halbur PG: Porcine respiratory disease complex. Proceedings of the North Carolina Healthy Hogs Seminar; 1997 [http://www.ncsu.edu/project/swine_extension/healthyhogs/ book1997/halbur2.htm.]

3. Sorensen V, Jorsal SE, Mousing J: Diseases of the respiratory system. In Diseases of Swine. 9th edition. Edited by Straw BE, Zimmerman JJ, D’Allaire S, Taylor DJ. Oxford: Blackwell Publishing; 2006:149-177.

4. Thacker EL, Halbur PG, Ross RF, Thanawongnuwech R, Thacker BJ: Mycoplasma hyopneumoniae potentiation of porcine reproductive and respiratory syndrome virusinduced pneumonia. J Clin Microbiol 1999, 37:620-627.

5. Palzer A, Ritzmann M, Wolf G, Heinritzi K: Associations between pathogens in healthy pigs and pigs with pneumonia. Vet Rec 2008, 162:267 - 271.

6. Hansen MS, Pors SE, Jensen HE, Bille-Hansen V, Bisgaard M, Flachs EM, Nielsen OL: An Investigation of the Pathology and Pathogens Associated with Porcine Respiratory Disease Complex in Denmark. J Comp Pathol 2010, 143:120-131.

7. Fablet C, Marois-Cre'han C, Simon G, Grasland B, Jestin A, Kobisch M, Madec F, Rose

8. N: Infectious agents associated with respiratory diseases in 125 farrow-to-finish pig herds: A cross-sectional study. Vet Microbiol 2012, 157:152-163.

9. Karniychuk UU, Nauwynck JH: Performance of assays for testing antibodies against porcine reproductive and respiratory syndrome virus in sera collected from swine farms in a region with extreme virus heterogeneity. Acta Vet - Beograd 2014, 64: $44-51$.

10. Savic B, Ivetic V, Milicevic V, Pavlovic I, Zutic M, Gagrcin M: Genetic diversity of mycoplasma hyopneumoniae isolates from conventional farrow-to-finish pig farms in Serbia. Acta Vet Hung 2010 58:297-308. 
11. Savic B, Milicevic V, Jakic-Dimic D, Bojkovski J, Prodanovic R, Kureljusic B, Potkonjak, A, Savic B: Genetic characterization and phylogenetic analysis of porcine circovirus type 2 (PCV2) in Serbia. Arch Virol 2012, 157:21-28.

12. Ellis J, Spinato M, Yong C, West K, Mcneilly F, Meehan B, Kennedy S, Clark E, Krakowka S, Allan G: Porcine circovirus 2-associated disease in Eurasian wild boar. J Vet Diagn Invest 2003, 15:364-368.

13. Mayor D, Zeeh F, Frey J, Kuhnert P: Diversity of Mycoplasma hyopneumoniae in pig farms revealed by direct molecular typing of clinical material. Vet Res 2007, 38:391- 398.

14. Townsend KM, Boyce JD, Chung JY, Frost AJ, Adler B: Genetic Organization of Pasteurella multocida cap Loci and Development of a Multiplex Capsular PCR Typing System. J Clin Microbiol 2001, 39:924-929.

15. Schaller A, Djordjevic SP, Eamens GJ, Forbes WA, Kuhn R, Kuhnert P, Gottschalk M, Nicolet J, Frey J: Identification and detection of Actinobacillus pleuropneumoniae by PCR based on the gene apxIVA. Vet Microbiol 2001, 79:47-62.

16. Oliveira S, Galina L, Pijoan C: Development of a PCR test to diagnose Haemophilus parasuis infections. J Vet Diagn Invest 2001 13:495-501.

17. Marois C, Bougeard S, Gottschalk M, Kobisch M: Multiplex PCR assay for detection of Streptococcus suis species and serotypes 2 and $1 / 2$ in tonsils of live and dead pigs. J Clin Microbiol 2004, 42:3169-3175.

18. Ertaş HB, Kiliç A, Özbey G, Muz A: Isolation of Arcanobacterium (Actinomyces) pyogenes from abscessed kidney and identification by PCR. Turk J Vet Anim Sci 2005, 29:455-459.

19. Stadejek T, Oleksiewicz MB, Potapchuk D, Podgorska K: Porcine reproductive and respiratory syndrome virus strains of exceptional diversity in eastern Europe support the definition of new genetic subtypes. J Gen Virol 2006, 87:1835-1841.

20. Spackman E, Dennis AS, Myers TJ, Bulaga LL, Garber LP, Perdue ML, Lohman K, Daum LT, Suarezi DL: Development of a real-time reverse transcriptase PCR assay for type A influenza virus and the avian H5 and H7 hemagglutinin subtypes. J Clin Microbiol 2002, 40:3256-3260.

21. Opriessnig T, GiménezLirola LG, Halbur PG: Polymicrobial respiratory disease in pigs. Anim Health Res Rev 2011, 12:133-148.

22. Kim J, Chung HK, Chae C: Association of porcine circovirus 2 with porcine respiratory disease complex Vet J 2003, 166:251-256.

23. Ciprian A, Pijoan C, Cruz T, Camacho J, Tòrtora J, Colmenares G, Lopez-Revilla R, de 1 a Garza M: Mycoplasma hyopneumoniae Increases the Susceptibility of Pigs to Experimental Pasteurella multocida Pneumonia. Can J Vet Res 1988, 52:434-438.

24. Rapp-Gabrielson VJ, Simone R, Oliveira P, Pijoan C: Haemophilus parasuis. In Diseases of Swine. 9th edition. Edited by Straw BE, Zimmerman JJ, D'Allaire S, Ta ylor DJ. Oxford: Blackwell Publishing; 2006:681-690

25. Solano GI, Segales J, Collins JE, Molitor TW, Pijoan C: Porcine reproductive and respiratory syndrome virus (PRRSV) interaction with Haemophilus parasuis. Vet Microbiol 1997, 55:247-257.

26. Taylor DV: Miscellaneous Bacterial Infections - Arcanobacterium pyogenes. In Diseases of Swine. 9th edition. Edited by Straw BE, Zimmerman JJ, D'Allaire S, Ta ylor DJ. Oxford: Blackwell Publishing; 2006:841-843. 
27. Galina L, Pijoan C, Sitjar M, Christianson WT, Rossow K, Collins JE: Interaction between Streptococcus suis serotype 2 and porcine reproductive and respiratory syndrome virus in specific pathogen-free piglets. Vet Rec 1994, 134:60-64.

\section{IDENTIFIKACIJA INFEKTIVNIH AGENASA U KOMPLEKSU RESPIRATORNE BOLESTI SVINJA (PRDC) NA FARMAMA SVINJA U SRBIJI PRIMENOM REAKCIJE LANČANE POLIMERAZE (PCR)}

SAVIĆ Božidar, RADANOVIĆ Oliver, JOVIČIĆ Dubravka, NEŠIĆ Ksenija, IVANOVIĆ Snežana, STEVANČEVIĆ Ognjen, CVETOJEVIĆ Đorđe, KASAGIĆ Dragan

U cilju identifikacije, utvrđivanja prevalence i interakcije multiplih infektivnih agenasa u kompleksu respiratorne bolesti svinja (PRDC), retrospektivno je pregledano 235 uzoraka tkiva pluća poreklom od prirodno inficiranih svinja. Uzorci su analizirani reakcijom lančane polimeraze (PCR) na prisustvo Porcine circovirus tip 2 (PCV2), Virus reproduktivnog i respiratornog sidroma svinja (PRRSV), Virus influence svinja (SIV), M yooplasma hyopneumoniae (Mhp), Pasteurella multocida (Pm), A ctinobacillus pleuropneumoniae (App), H aemophilus parasuis (Hps), Streptococaus suis (Ssuis) i A ranobacterium pyogenes (Apyo). $\mathrm{U}$ ispitivanim uzorcima, ukupno je ustanovljeno 49 različitih kombinacija virusnih i bakterijskih patogena. Koinfekcije virusnih i/ili virusnih i Mhp infekcija sa odgovarajućim bakterijskim patogenima su ustanovljene u pet različitih kombinacija. Mono bakterijske infekcije su detektovane u 150, a poli-bakterisjke infekcije su ustanovljene u 85 ispitivanih uzoraka. PCV2 je najfrekventnije detektovani virus, a Pm je najznačajniji sekundarni bakterisjki respiratorni patogen ustanovljen u ispitivanim PRDC slučajevima. Razlog zbog koga je PRDC trenutno najfrekventnije ustanovljena respiratorna afekcija svinja u Srbiji je najverovatno zbog prisustva većeg broja fakotra rizika u konvencionalnim zatvorenim sistemima gajenja svinja. 